\title{
肺癌に対するゲフィチニブ投与中に根治手術を行った 甲状腺乳頭癌の一例
}

\author{
新川智佳子 浅野敬 史 \\ 天野真太郎那須隆
}

要旨：現在，様々な悪性腫瘍に対する分子標的薬の効果が報告され，生命予後が改善してきている。これによ り，続発する重複癌に対する治療を要する症例もみられるようになった。今回，肺癌に対しゲフイチニブ（イ レッサ $\left.{ }^{\circledR}\right)$ を投与され，PRが得られていた症例に対し，甲状腺全摘術，頸部郭清術を施行した甲状腺乳頭癌 症例を経験した。ゲフィチニブによる創傷治癒遅延の可能性も考えられたため, 11 日間の休薬期間を設けた。 術後は創部の合併症を認めず，ゲフィチニブ休薬に伴う肺癌の増大を認めなかった。重複癌症例では，一次癌 の治療継続の可否や，二次癌に対する治療の根治性や安全性などの問題があげられる。このような問題につい て, 文献的考察を加え報告する。

キーワード：上皮成長因子チロシンキナーゼ阻害薬, 二次癌, 創傷治癒遅延, ゲフィチニブ

Summary The experience of thyroid papillary carcinoma as secondary cancer during administration of gefitinib for lung cancer:

Chikako Shinkawa, Takashi Asano, Shintaro Amano and Takashi Nasu. Department of Otolaryngology, Head and Neck Surgery, Yamagata-city hospital Saiseikan

Epidermal growth factor receptor (EGFR) tyrosine kinase inhibitors improve the prognosis of cancer patients and bring many treatment options. We often experience patients with secondary cancer during the treatment for primary cancer. A 76-year-old man, who taking gefitinib for lung cancer, visited our hospital complaining of hoarseness, and was diagnosed with thyroid papillary carcinoma. We planned total thyroidectomy and neck dissection. We stopped the administration of gefitinib 5 days before and after the operation because the mechanism of action of gefitinib was expected to delay wound healing. As a result, a delay in wound healing and progression of lung cancer did not occur. In the future, there will be many cases of double cancer or secondary cancer. Currently, there are many options for cancer treatment: surgery, chemotherapy, biotherapy, radiotherapy and their combinations. We must accumulate experience of therapies for multiple cancer and establish the risk and safety of combination therapy.

Key words: epidermal growth factor receptor tyrosine kinase inhibitor, secondary cancer, epithelial wound healing delay, gefitinib

山形市立病院済生館 耳鼻咽喉 - 頭頸部外科

[令和元年 10 月 23 日受付, 令和 2 年 3 月 5 日受理］
はじめに

現在, 様々な悪性腫瘍に対する分子標的薬の効果 が報告され，治療適応が拡大されてきている。この 治療効果により, 生命予後の延長が得られる中, 続 発する重複癌に対する治療を必要とする症例もみら 
れるようになった。

今回, 肺癌に対するゲフィチニブ (イレッササ $\left.{ }^{\circledR}\right)$ 内 服中に甲状腺全摘を施行した症例を経験した。ゲ フィチニブは上皮成長因子受容体 (Epidermal Growth Factor Receptor, EGFR) チロシンキナー ゼ阻害薬であり, EGFR 遺伝子変異陽性の手術不能 または再発非小細胞肺癌を適応症とした薬剤であ る。EGFR は上皮性悪性腫瘍に過剩発現するだけで なく，正常皮膚の上皮基底層や脳，骨髄，筋肉など 全身に広範囲に発現している。EGFR は受容体型于 ロシンキナーゼのひとつであり, EGFR に EGFや TGF- $\alpha$ などの増殖因子が結合すると, 細胞内のチ ロシンキナーゼに ATP が結合することでリン酸化 が起こり, 連鎖的に細胞増殖シグナルが伝達され る。癌細胞における EGFR のリン酸化を阻害し, 癌細胞のシグナル伝達を遮断するのがゲフィチニブ であり，それによって癌の増殖や血管新生，浸潤が 抑制されると考えられている。また, 表皮細胞に発 現している EGFRにEGF や TGF- $\alpha$ が結合すると, 表皮細胞の増殖が充進し, 創傷治癒が促進され る1)。ゲフィチニブは表皮細胞における EGF の働 きも阻害するため, 副作用として発疹や皮膚乾燥 症, 痤瘡様皮膚炎が起こるだけではなく, 創傷治癒 の遅延が危惧される。

分子標的薬投与中, もしくは投与後の患者に対す る外科治療について一定の指針はなく, 個々の症例 に応じた対応をしているのが現状である。今回，ゲ フィチニブを休薬し甲状腺全摘を施行した甲状腺乳 頭癌症例を報告し，周術期に打ける分子標的薬の取 扱いについて文献的考察を加えて報告する。

\section{症例}

症例 : 76 歳, 男性。

主訴：嗄声。

既往歴: 胃癌に対する胃全摘術後。前立腺肥大症。 肺腺癌。

現病歴 : 2 年前に肺癌の診断 (cStage IIIB) を受 け, 組織病理検査では adenocarcinoma, EGFR 遺 伝子変異陽性であったため, ゲフィチニブ内服加療 により PR の状態であった。3 か月前から嗄声を自 覚し，当科を受診した。

初診時現症：触診上, 前頸部には腫瘤は認めず, その他リンパ節の腫脹もはっきりしなかった。喉頭 は右声带が傍正中位で固定し, 弓状化していた。

血液検查所見：サイログロブリンが $138 \mathrm{ng} / \mathrm{mL}$ と上昇していた。抗サイログロブリン抗体や抗 TPO 抗体は陰性だった。また, へモグロビンが $9.8 \mathrm{~g} / \mathrm{dL}$ と軽度の貧血, クレアチニンが $1.07 \mathrm{mg} / \mathrm{dL}$
と軽度腎機能障害を認めたが, アルブミンも $3.9 \mathrm{~g} /$ $\mathrm{dL}$ と低下なく栄養状態は良好で, 肝障害も認めな かった。

頸部超音波検査: 甲状腺右葉に $2.12 \times 1.43 \mathrm{~cm}$ の 充害性腫瘍を認めた。明らかな石灰化は認めず，被 膜外浸潤を疑う所見は明らかではなかった（図 1A）。その尾側には腫脹したリンパ節を認めた（図 $1 \mathrm{~B})$ 。リンパ節は $0.9 \mathrm{~cm}$, 円形でリンパ節門は消失 していた。

CT (図 2): 甲状腺右葉に $2 \mathrm{~cm}$ 大の腫瘍性病変 を認め, 胸骨甲状筋への被膜外浸潤も否定できな かった (矢印)。またその背側から尾側には気管傍 リンパ節の腫脹を認め, 気管への浸潤が疑われた (矢頭)。さらに $1 \mathrm{~cm}$ 未満だが, 右上内深頸リンパ 節も認めた。

MRI：CT と同様に甲状腺右葉に腫瘤を認めた。 右気管傍リンパ節は明らかな気管への浸潤は認めな かった（図 3 , 矢頭)。

穿刺吸引細胞診 : papillary carcinoma の診断で あった。

以上から, 甲状腺乳頭癌 T3bN1bM0 cStage II と 診断し, 甲状腺全摘, 頸部リンパ節郭清（D2a）を 計画した。EGFの働きを阻害するゲフィチニブの 影響で術後の創傷治癒遅延が予想されたため, 呼吸 器内科主治医との相談のもと, 手術前後で休薬する 方針とした。休薬期間に関しては Wakelingら ${ }^{2)} の$ 報告を参考に術前 5 日目から休薬, 術後 5 日目に再 開し，休薬期間は 11 日間とした。

術中所見: 乳様突起から胸骨切痕の約 2 横指頭側 を通るような, 逆 J字の皮膚切開をおき, 広頸筋下 で皮弁を拳上した。甲状腺腫瘍は肉眼的に明らかな 被膜外浸潤を認めなかったが，安全域を確実にする ために右胸骨甲状筋は合併切除した。右気管傍リン パ節が右反回神経に強く癒着しており腫瘍の浸潤と 考えられたため, 反回神経は合併切除し, 神経断端 を頸神経ワナに 8-0 ナイロンで吻合した。また, 転 移リンパ節は気管外側壁への浸潤もみとめたが, 気 管外側壁を削ぐような形で切除可能だった。閉創は 4-OPDS で広頸筋層, 皮下組織を縫合し, 皮膚はス キンステープラーで縫合した。手術全体を通して, 易出血性や組織の痏痕化など, ゲフィチニブ投与に よる頸部組織への影響を疑わせるような変化は認め なかった。

術後病理診断: 甲状腺乳頭癌 pT4aN1a の診断で あり胸骨甲状筋への被膜外浸潤も認めた。右気管傍 リンパ節は節外浸潤を伴い, 反回神経にも浸潤して いた。また, 右上内深頸りンパ節へも複数個の転移 も認めた。 


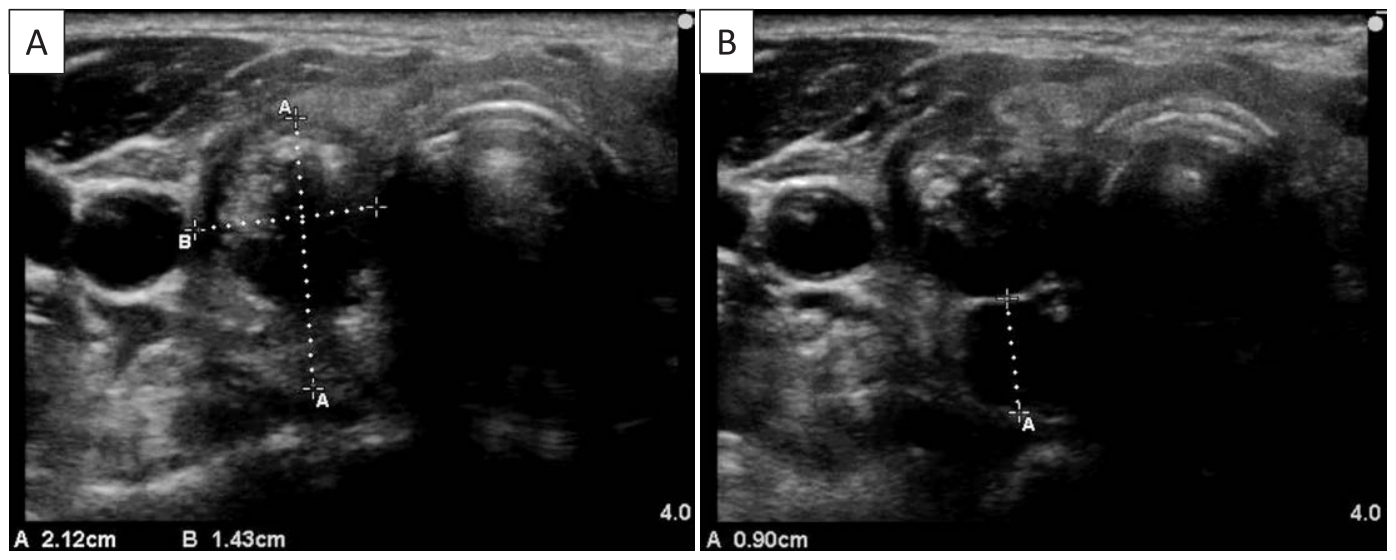

図 1 頸部超音波検査

$\mathrm{A}$ ：甲状腺右葉に $2.12 \times 1.43 \mathrm{~cm}$ の腫瘤を認めた。石灰化は認めず，被膜外浸潤を疑うような 所見も認めなかった。

$\mathrm{B}$ ：甲状腺右葉の尾側深部には円形のリンパ節を認め,リンパ節門は認めなかった。

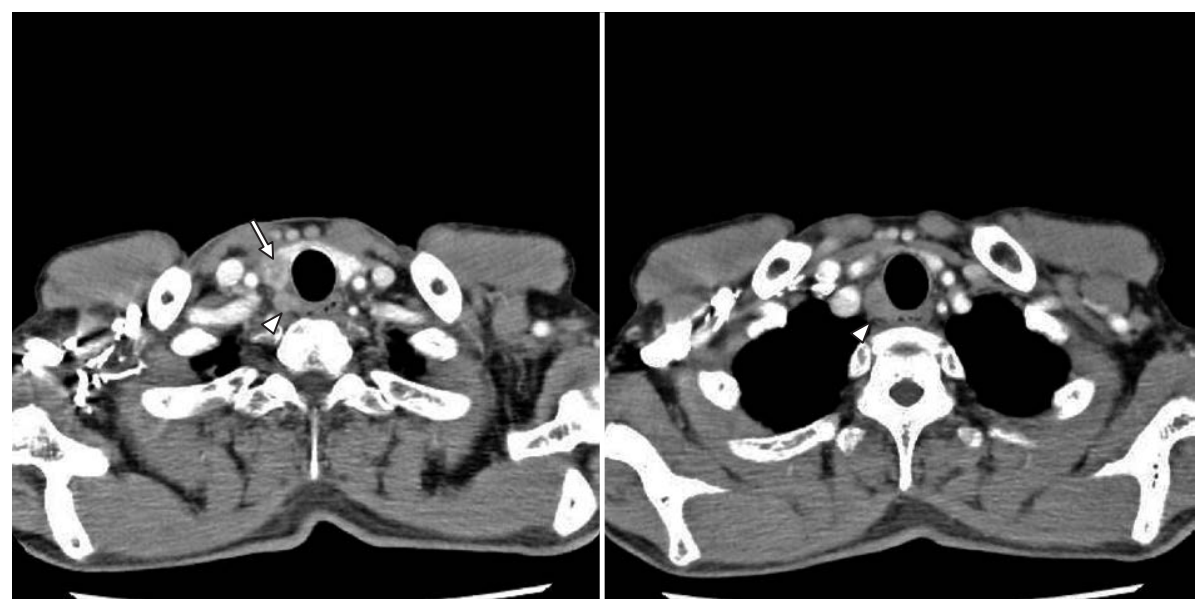

図 2 CT 所見

甲状腺右葉に約 $2 \mathrm{~cm}$ 大の造影効果のそしい腫瘤を認めた（矢印）。その背側か ら尾側に右気管傍リンパ節の腫脹を認め，大きさは $2 \mathrm{~cm}$ 程度であった（矢頭）。

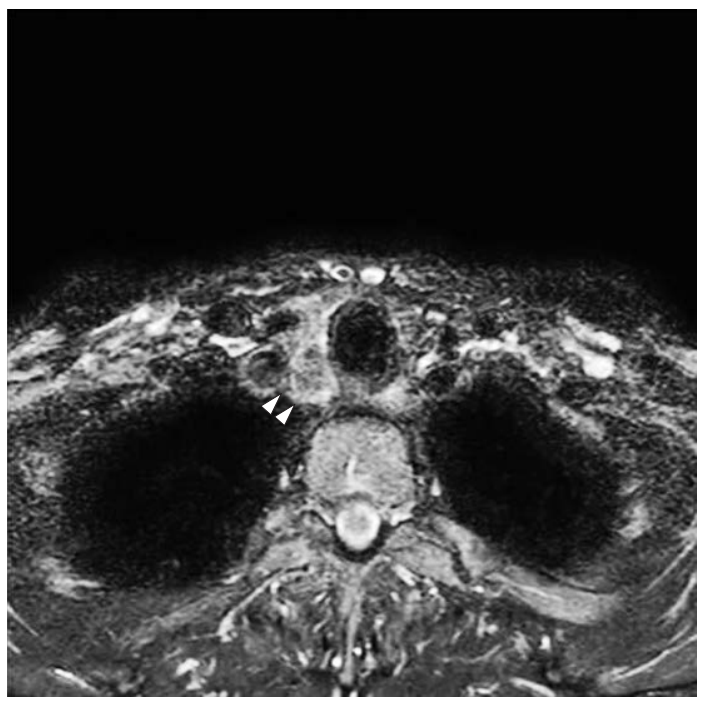

図 3 MRI 所見

造影 MRI では明らかな気管浸潤は認めなかった。
術後経過：周術期に大きな問題はなく経過した。 当科では術後の抜系は通常術後 5 日目に施行してい るが, ゲフィチニブ投与による創傷治瘉遅延の可能 性を考え, 術後 7 日目に施行した。眓 4 は術後 2 週 間目の創部の状態であるが, 感染や縫合不全などの 所見を認めなかった。またゲフィチニブ休薬に伴う 肺癌の再増大も懸念されたが, 休薬前後で肺病変の 増大は認めず（図 5), 腫瘍マーカーである CEA の 再上昇も認めなかった。術後一年が経過し, 右声带 は固定したままだが, 術前に弓状化した右声帯に緊 張がもどり, 㖽声は改善傾向である。

\section{考察}

現在，シスプラチンをはじめとする殺細胞性の抗 癌剤に加え, 分子標的薬の適応が拡大され, 化学療 法の治療選択肢の幅が広がってきており，それによ 


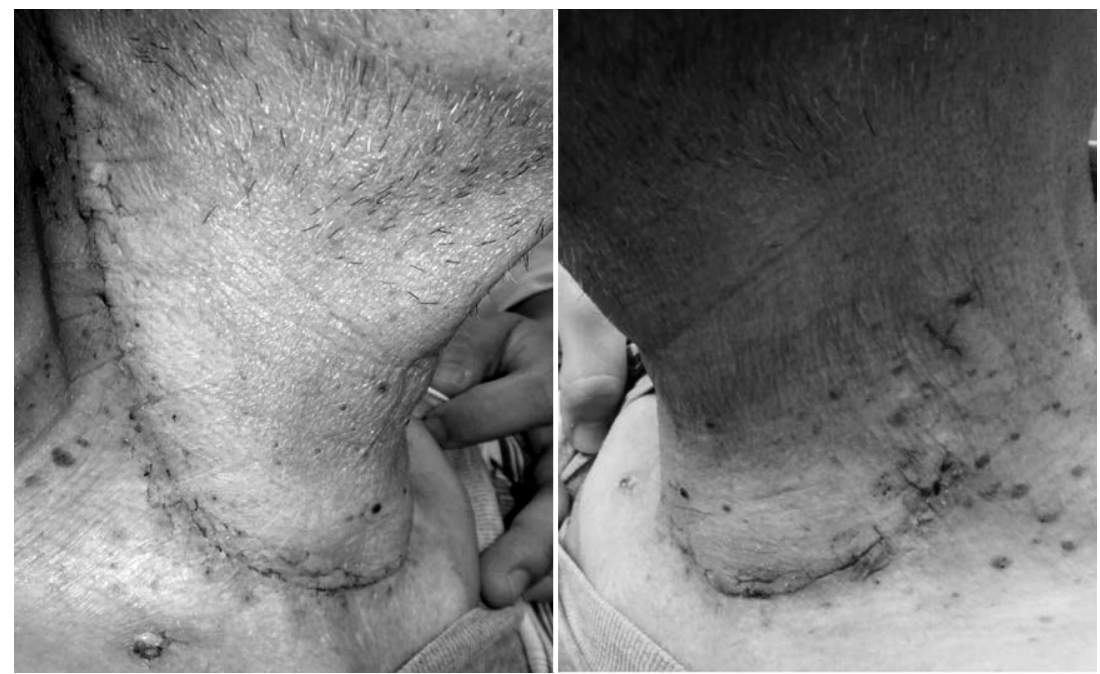

図 4 術後 2 週間目の創部

ゲフィチニブの作用機序から考えられる創傷治癒遅延は起こらず，創感 染や創離開は認めなかった。

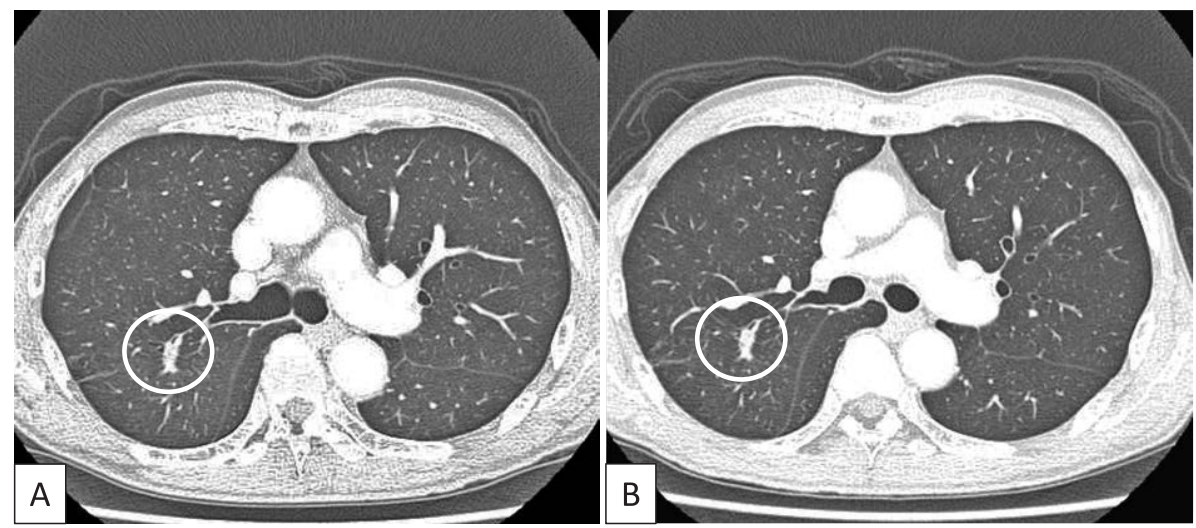

図 $5 \mathrm{~A}$ : 術前, B : 術後 1 か月後

術後 1 か月後では術前に比べて肺癌の増大は認めなかった。

り担癌状態で二次癌が見つかる症例を経験すること が増えてきている。このような患者に対して，一次 癌の治療と二次癌の治療をどのように両立させるか が検討課題となってきている。特に一次癌に対し分 子標的薬投与中の場合, 二次癌に対する手術治療を 行う際の分子標的薬の取扱いについて，明確な指針 がないのが現状である。

今回は肺癌に対するゲフィチニブ投与中に甲状腺 癌が発見された症例を経験した。Wakelingら 90 日のゲフィチニブ投与後にゲフィチニブを休薬 すると， 6 匹のうち 4 匹が休薬後約 10 日程度で, 腫瘍が再増大することを報告しており，この報告を 参考に術前 5 日間，手術当日，術後 5 日間，合計 11 日間の休薬期間を設定した。また，前述のよう にゲフイチニブは，作用機序から創傷治癒遅延の可 能性が示唆され，周術期の投与が創感染や創離開の 原因となることも懸念された。実際に，ラットの角
膜上皮においてゲフィチニブを前投与し，角膜損傷 を起こしてその修復過程をみた検討では， $\mathrm{S}$ 期の細 胞が減少, 修復した角膜の厚さが減少したという報 告がある ${ }^{3)}$ 。また，マウスに小腸切除を施行してゲ フィチニブを投与した場合, 回腸の重量, 絨毛の長 さ，陰窩の深さが減少したことから，小腸の生着を 阻害したとの報告もある4)。しかしいずれも，最終 的には創部は治癒している点から，ゲフィチニブ投 与が創部に与える臨床的影響は不明であり，投与自 体が外科治療を否定する根拠にはならないと考えら れる。さらには，肺癌に対する術前化学療法として ゲフィチニブを投与した報告をみると， 3 〜 週ゲ フィチニブを投与し，2 日〜 7 日の休薬期間を設け たのちに肺切除を施行したところ, 術後合併症とし て, air leakを認めた症例がそれぞれ，1/36 例 $(2.8 \%)^{5)} ， 1 / 23$ 例 $(4.3 \%)^{6)} ， 3 / 50$ 例 $(6.0 \%)^{7)}$ であっ たという報告がある。これに対し，ゲフィチニブを 
投与されていない通常の肺部分切除の縫合方法につ いての検討では約 $5.5 〜 22 \%$ の air leak があったと いう報告もあり ${ }^{8)}$ ，これらのデータから，ゲフィチ ニブの創傷治癒に与える影響は，臨床的には問題に なる可能性が少ないとも考えられる。しかしなが ら, 分子標的薬内服中の患者に対する外科治療の報告 が少ない現状では，皮弁を用いた再建手術などの手術 侵襲や年齢, 合併症の有無などを総合的に判断して休 薬期間を慎重に決定する必要があると考えられる。

頭頸部癌領域においては, 分子標的薬の中ではセ ツキシマブが適応を得ており，七ツキシマブと放射 線治療の組み合わせた Bioradiotherapy (BRT) が治 療選択肢のひとつとなった。しかしその後の救済手 術の安全性については一定の見解が得られていな い。Leon らは, 化学放射線治療 CRTを施行した 症例とセツキシマブ併用 BRT を施行した症例のう ち，局所再発をきたして救済手術を施行した症例の 検討を行い, BRT 群の方が術後合併症の発生頻度 が低かったことから，BRT は救済手術の CRT 後に 比較して, 合併症の頻度を減らす可能性があると報 告している ${ }^{9)}$ 。それに対し岸本らは CRT 後と同様 に, 組織の血流を考慮した慎重な手術操作，戦略が 必要と述べている10)。

現在，様々な分子標的薬が出現し，様々な癌腫に 対する効果が報告されており, 患者の生命予後の延 長が得られている。それに伴い, 一次癌の担癌状態 で二次癌が発見される症例が，今後も増えることが 予想され，そのような場合に治療戦略をどのように 立てるかが課題となってくる。本症例では分子標的 薬内服中に外科治療を要するケースであったが，今 後は外科治療のみならず，シスプラチンをはじめと する殺細胞性抗癌剂の治療を要する場合や放射線治 療を要する場合も考えられる。二次癌の存在が明ら かとなった場合に一次癌に使用している分子標的薬 に対する取扱いについて明確な指針はなく，今後は， これらの併用薬の安全性や相互作用などについて, 症例を重㸚て検討していく必要があると考えられる。

\section{まとめ}

ゲフィチニブ投与中に甲状腺全摘, 頸部郭清術 （D2a）を施行した甲状腺乳頭癌症例を経験した。 今後も重複癌症例の治療経験を重放, 分子標的薬の 安全性を確立していく必要があると考えられた。
著者は申告すべき利益相反を有しない。

\section{文献}

1）飯塚 一, 青柳 俊: 創傷治瘾における表皮細胞の 增殖制御。皮膚，38：132-147，1996。

2) Wakeling AE, Guy SP, Woodburn JR, et al: ZD1839 (Iressa): an orally active inhibitor of epidermal growth factor signaling with potential for cancer therapy. Cancer Res 62:5749-5754, 2002.

3) Nakamura Y, Sotozono C, Kinoshita S: The epidermal growth factor receptor (EGFR) : role in corneal wound healing and homeostasis. Exp Eye Res 72 : 511-517, 2001.

4) O'Brien DP, Nelson LA, Williams JL, et al: Selective inhibition of the epidermal growth factor receptor impairs intestinal adaptation after small bowel resection. J Surg Res $105: 25-30,2002$.

5) Lara-Guerra H, Waddell TK, Salvarrey MA, et al: Phase II study of preoperative gefitinib in clinical stage I non-small-cell lung cancer. J Clin Oncol 27 : 6229-6236, 2009.

6) Haura EB, Sommers E, Song L, et al: A pilot study of preoperative gefitinib for early-stage lung cancer to assess intratumor drug concentration and pathways mediating primary resistance. J Thorac Oncol $5: 1806-1814,2010$.

7) Rizvi NA, Rusch V, Pao W, et al: Molecular characteristics predict clinical outcomes: prospective trial correlating response to the EGFR tyrosine kinase inhibitor gefitinib with the presence of sensitizing mutations in the tyrosine binding domain of the EGFR gene. Clin Cancer Res $17: 3500-3506,2011$.

8）戸矢崎利, 富岡 泰, 千葉 直, 他 : 自動綘合器を 用いない胸腔鏡下肺部分切除術. 日本呼吸器外科学 会雑誌， 31：13-19， 2017.

9) Leon X, Aguero A, Lopez M, et al: Salvage surgery after local recurrence in patients with head and neck carcinoma treated with chemoradiotherapy or bioradiotherapy. Auris Nasus Larynx $42: 145-149$, 2015.

10）岸本 曜, 北村 守, 楯谷一, 他: 進行頭頸部癌 分子標的薬併用放射線療法後再発に対する救済手術 の経験. 日本気管食道科学会会報, 67：264-271, 2016. 